\title{
A perfect storm: The ramifications of Cape Town's drought crisis
}

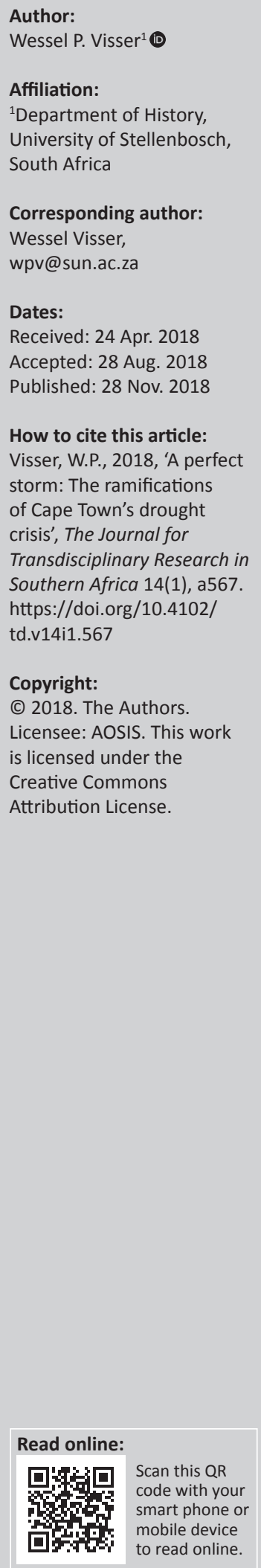

\begin{abstract}
By 2018, the City of Cape Town (CCT) suffered a third consecutive year of serious drought. This article investigates the chronology of the drought and the various measures imposed by the city council to preserve dwindling water supplies in an effort to stave off the so-called 'Day Zero' scenario when its water reserves would apparently dry up. By means of contemporary sources, water governance sources and other relevant documentation, the trajectory of Cape Town's water crisis and the political ramifications for its citizens is being investigated. Finally, lessons to be learnt from Cape Town's dealing with its drought crisis, and other cities that found themselves in similar situations, will be discussed. An analysis of the political fallout and blaming of who should be held responsible for Cape Town's precarious water situation is also presented. It seems that a combination of factors was responsible for the city's relative unpreparedness in dealing with the drought: the politically fractured nature of South African multi-tiered government agencies and the lack of an integrated government approach to the drought; the CCT mayor's unclear and negative communication to rate payers and ineffective water-saving proposals; a fallout between the CCT mayor and her political superiors over the effectiveness of her drought management plans; a dysfunctional, bankrupt and inert national Department of Water and Sanitation; and the expectation that the city's expenditure on water supply schemes could be put on hold simply by saving the existing supply in the belief that it would remain stable.
\end{abstract}

\section{Introduction}

A recent BBC report, quoted by Heymans (2018), identified 11 cities - Cape Town, London, Cairo, São Paolo, Mexico City, Bangalore, Beijing, Moscow, Tokyo, Miami and Jakarta, which 'could run out of water' in the next decade or so. By 2018, the citizens of Cape Town, South Africa, who had been suffering a persistent drought since 2015, found themselves in a proverbial 'perfect storm'1: the most severe drought within the city's living memory, a dysfunctional national Department of Water and Sanitation (DWS), which was supposed to serve as custodian of all water affairs in South Africa and political infighting and disunity within the Cape Town city council in dealing with the crisis.

With a population of 3.7 million, the City of Cape Town (CCT) enjoys a Mediterranean climate, the average summer temperature is $26^{\circ} \mathrm{C}$ and the average winter temperature is $16^{\circ} \mathrm{C}$. The average annual precipitation is $520 \mathrm{~mm}$, the wettest months being June to August (World Weather \& Climate Information 2018). The city's water is transferred from several catchment areas through an intricate system of dams and pipelines managed either by the CCT or the national DWS. The collective capacity of the city's 14 dams is approximately $900000 \mathrm{~mL}$. Most of this capacity is provided by six large dams: the Steenbras Upper and Lower dams (city-controlled), Wemmershoek (city-controlled) and the Voëlvlei, Theewaterskloof (see Figure 1) and Berg River dams (all statecontrolled). The state-controlled dams also provide water for agricultural and irrigation purposes. The city's and the state's integral water scheme in the Western Cape also provides potable water to towns adjacent to and on the periphery of the greater Cape Town metropolitan area, with the result that in total approximately 8 million people are dependent on the overarching water supply system (City of Cape Town 2011).

\section{Comparative drought case studies}

The Cape Town drought seems to be following a pattern similar to those of Melbourne, Barcelona and São Paolo.

From 1997 to 2009, Australia faced the worst drought in the country's recorded history, the socalled 'Millennium Drought'. Melbourne, a city of 4.3 million people located in south-eastern 1.A detrimental or calamitous situation or event arising from the powerful combined effect of a unique set of circumstances 


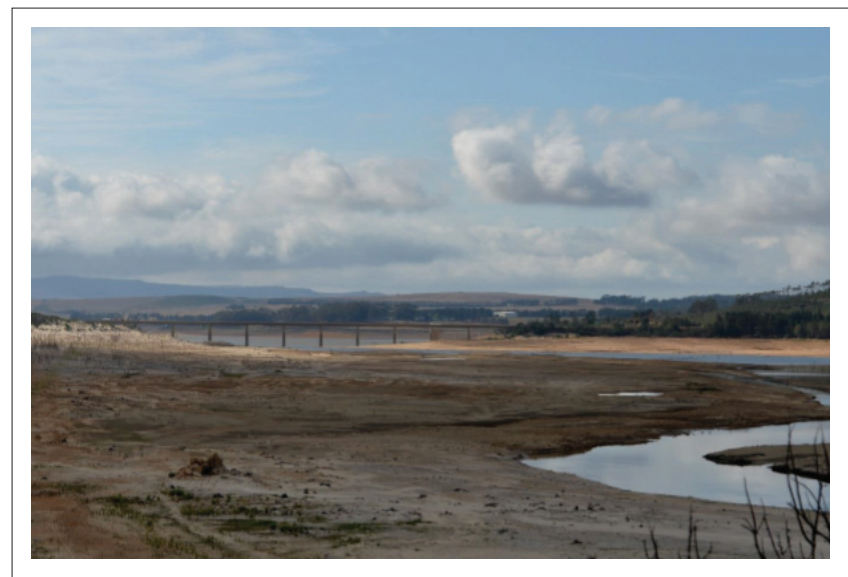

Source: Photo courtesy of Sterna Botha, Villiersdorp, 29 January 2018

FIGURE 1: Theewaterskloof dam levels in January 2018.

Australia, was worst hit. Water levels dropped to an all-time low capacity of $25.6 \%$ before the drought eased in 2010 . The city was successful in reducing water demand per capita by almost $50 \%$ by implementing various policy and infrastructure innovations. Legislation was passed that allowed the federal government to provide funding to Melbourne and to set the groundwork for an integrated government response to the drought. Initiatives implemented to combat the drought included water restrictions and a complete ban on outdoor use of municipal water; the fixing of water pipe leakages and the implementation of flow control devices, the construction of a water pipeline to deliver water from a river basin and a treatment plant for recycled water to augment Melbourne's water supply; rebate programmes for residential greywater systems, washing machines, toilet and showerhead replacement services, hot water re-circulators and rainwater tank installations; storm water harvesting; the installation of water-efficient evaporative coolers for air conditioners; the reduction of water flowing to rivers, as well as electronic billboard and media advertising campaigns to promote water conservation, education and awareness especially in primary and secondary schools (Low et al. 2015; Patterson 2015; Tam 2016; Slaughter \& Mantel 2018).

In 2008, the 5.5 million inhabitants of the Mediterranean city of Barcelona, capital of Catalonia in Spain, experienced its worst drought in 70 years: a warming up and drying out of the regional climate, failing winter rains, dwindling reservoir water levels and increasing water demands, increased housing development because of rapid population expansion, unpopular emergency water-saving measures and extreme short-term measures similar to those of Melbourne, a lack of foresight on the side of the authorities, political battles and controversy and differences in strategy to deal with the crisis, as well as negative publicity (Goodman 2008; Nash 2008). Barcelona's long-term solution to the problem was the construction of a seawater desalination plant at a cost of 230 million euros. It has a drinking water output of $200000 \mathrm{~m}^{3}$ per day which caters to 1.3 million people in the region or $20 \%$ of the population of Catalonia (Van Zyl 2018).
The 2014-2017 Brazilian drought affected the southeast of Brazil and especially the metropolitan areas of São Paolo with its 20 million inhabitants where it has been described as 'the worst drought in 80 years'. Warnings about the coming drought by scientists, environmentalists and technical experts were overridden by real estate developers and industrial and agricultural interests. The drought was characterised by water rationalisation, low-pressure flow in pipes and dry taps sometimes for days on end, with residents turning to drilling private wells, recycling water, harvesting rainwater, hoarding potable water and buying expensive private water from tank trucks to avoid relying on the city's water network. Direct water allocations to agriculture and industry were also suspended and punitive tariffs imposed on users, but still the levels of the city's main reservoirs dropped below $17 \%$. Citizens' protests soon followed and as the drought worsened by 2016, a state of emergency was declared across the state. Long-term solutions included the transfer of more water from additional river basins (Gerberg 2015; Nikolau 2015; Rigby 2015; Stauffer 2016).

However, unlike Melbourne, São Paolo and Barcelona, where water-saving measures were introduced and the droughts eventually broken, Cape Town could become the first world city to virtually run out of water as a so-called 'Day Zero' was set originally for July 2018 by the city council, should most water supplies be exhausted and when $75 \%$ of the city's taps will be turned off (May 2018; Theron \& Brits 2018).

By means of contemporary sources, water governance sources and other relevant documentation, this article investigates the trajectory of Cape Town's water crisis and the political ramifications for its citizens. Finally, lessons to be learnt from Cape Town's dealing with its drought crisis and other cities that found themselves in similar situations will be discussed.

\section{Ignoring the warnings of 'water prophets'}

Water awareness was highlighted as early as 1970 when FA Venter, a prominent Afrikaans writer, was commissioned by the then Minister of Water Affairs to write a report on water in South Africa. The 568 pages report stated that drastic measures were needed to prevent the country from running out of water by the year 2000 (Ismail 2018). Twenty years later, in 1990, the South African Water Research Commission (Streek 1990) predicted that Cape Town's water supplies were expected to dry up by 2007 as the city's fresh water supplies would by then be fully committed. In the post-2007 period, the feasibility of reclaiming purified sewage effluent to augment supplies would have to be investigated.

In the late 1990s, two University of Cape Town zoologists, Davies and Day (1998), warned in their book Vanishing Waters that South Africa was rapidly running out of water because the demand was rapidly outstripping supply. The hugely increasing human population required more and more water 
and many people were competing for too little available water. South Africa had close to the lowest conversion of rainfall to usable runoff from rivers of all countries in the world, but still the demand for water was increasing exponentially. They predicted that the country had between 10 and 15 years left before a situation of 'permanent drought' would have been reached - the stage at which the resource simply cannot provide for further increases in demand. Davies and Day advocated for the immediate implementation of a public education programme and the initiation of demand management rather than water supply management strategies.

Barnes (2016) argues that the 2015-2018 Cape Town drought had been expected by meteorologists for at least a decade and that the government had been alerted to this risk for many years. Similar sentiments were echoed by Turton (2015), he referred to the 1970 report of the Commission of Enquiry into Water Matters which warned of:

serious shortages...somewhere before the close of the century unless essential steps were taken to plan the exploitation and augmentation or our water resources, to conserve and re-use our available supplies, and to manage and control our resources in the most efficient manner (Turton p5).

But according to Turton, the ruling African National Congress (ANC) 'seemed to regard the Commission's report as an apartheid instrument which should simply be jettisoned'.

\section{A chronology of the Cape Town drought}

The city's current water crisis followed after three consecutive years of below average rainfall in the city's catchment areas, coupled with a strongly developed El Niño weather pattern and an urban population growing by $4 \%$ each year (SADC 2016). Since 2015 , the press began to report more regularly about the continued drop of water levels of Cape Town's six major dams even during the traditional rain season of June to August (Janse van Rensburg 2015). Although the municipal council initially stated that there was 'no concern' over the city's water content, level 2 water restrictions were imposed since January 2016. Agriculture, however, was exempted from the restrictions. A $20 \%$ saving of water among residential and business customers was being promoted but a daily basic allowance of $6 \mathrm{~kL}$ free water was still granted to poorer households, although punitive measures were introduced for serious offenders of the restrictions. The water shortfall in the catchment areas was seen as evidence that the climate was becoming increasingly unpredictable. By November 2016, level 3 restrictions were imposed prohibiting inter alia the outdoor use of domestic hosepipes (Muller 2017a).

By February 2017, the drought took a turn for the worse when the levels of Theewaterskloof, the city's largest supply dam, dropped to $34 \%$. Consequently, level 3B water restrictions were imposed, targeting a 30\% reduction in use. The highest 20000 water users were to be targeted with punitive measures such as fines for transgressions or the installation of water restriction devices unless they reduced their consumption by $20 \%$. Gardens, sports fields and parks could be watered only twice a week, using a bucket or watering can. A media campaign was launched to inform Capetonians about the gravity of the drought and to encourage continuous water preservation. The CCT also began to launch a 'name and shame' media campaign to expose repeat water restriction offenders. At that stage, the city council still deemed the construction of desalination plants to replenish the dwindling water supply too expensive in terms of its impact on water tariffs for the citizens (Muller 2017a).

In March 2017 the Western Cape provincial government declared the province a disaster area to avoid a so-called 'Day Zero'. The water management strategy changed from water supply management to water demand management. Most of Cape Town's municipal swimming pools were closed and water pressure was decreased in the reticulation system in order to diminish water consumption (Nienaber 2017a). In June, level 4 water restrictions were introduced and Executive Mayor Patricia de Lille referred to water shortage as the 'new normal' in Cape Town. Municipal water for outdoor use and domestic garden irrigation was prohibited and could be utilised only for drinking, cooking and essential washing. Greywater toilet flushing was encouraged and commercial waterless car wash products were introduced (Felix 2017). When a disappointing 2017 low winter rainfall season became apparent, level $4 \mathrm{~B}$ restrictions were implemented. Citizens were encouraged to limit their personal water usage to $87 \mathrm{~L}$ per day and the city council attempted to curtail the metropole's water usage to 500 million litres per day. The city's basic allowance of $6 \mathrm{~kL}$ free water was terminated except for registered poor families (Nienaber 2017b). Contributing to the problem is the fact that since 1995, Cape Town's population has grown by 55\%, but over the same period, dam storage has increased by only 15\% (Anonymous 2017a).

By September 2017, the usable water levels of the city's storage dams dropped to $27.8 \%$ and level 5 restrictions were introduced. The city council demanded that water usage of commercial properties be lowered by another $20 \%$, while domestic households were restricted to $20 \mathrm{~kL}$ per day. Mayor Patricia de Lille also encouraged citizens to store potable water (see Figure 2) 'should their municipal supply be interrupted'. Although water consumption had been reduced by $27 \%$, it was still 137 million litres more than the targeted 500 million litres per day (Breytenbach 2017a). By October 2017, large-scale emergency water augmentation plans, announced 2 months earlier to provide between 200 and 450 million litres potable water daily, such as drilling into aquifers and the construction of temporary desalination plans, had still not been commissioned. At that stage, the city was still consuming 610 million litres daily instead of a targeted 500 million litres. 


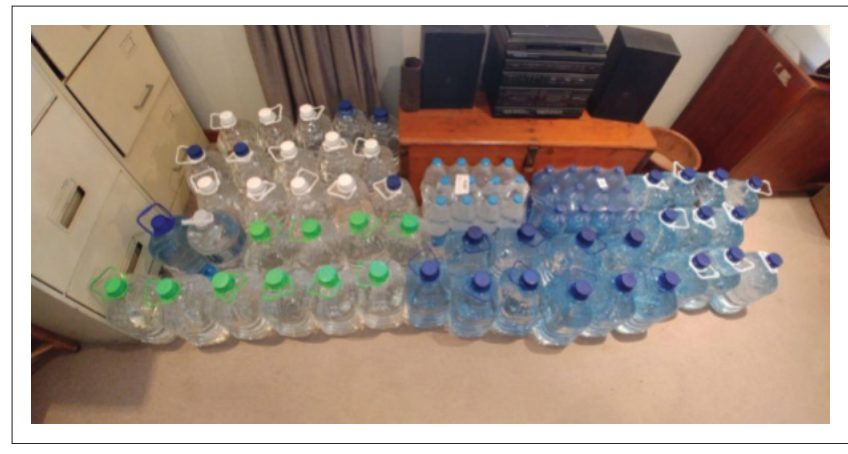

Source: Photo courtesy of author's private water research photo collection, May 2018 FIGURE 2: Residential hoarding of potable water for a possible 'Day Zero'.

Furthermore, it came to light that the envisioned alternative sources would actually produce only between 150 and 250 million litres per day and city officials were accused of 'not doing their homework properly' (May 2018). Plans to provide 200 water points which would be established all over the city where its 3.7 million inhabitants could collect a daily water ration of $25 \mathrm{~L}$ per person from 'Day Zero' onwards were also revealed to the media. The 'Day Zero plan' would be the point where a Disaster Risk Management Centre introduces phase 2 of its plan, to be triggered when the city's six major dams supplying Cape Town reach a storage level of $13.5 \%$. Water restrictions would move from level $6 \mathrm{~b}$ to level 7 and $75 \%$ of the city's taps would be turned off, leaving just enough water to supply critical services such as hospitals, old age homes, certain schools and the designated collection sites across the city (May 2018; Winter 2018).

Although aerial surveys and mapping for potential groundwater sources as well as drilling operations into aquifers in Cape Town's mountainous catchment areas finally commenced in November 2017 (Brits 2017), the city's water situation became dire when the summer heatwaves hit the Western Cape. Since the beginning of December, level 6 water restrictions came into being. Non-residential properties had to decrease their quota from the city's dams further by $45 \%$ and the DWS cut agriculture's allocation from these dams by $60 \%$. Commercial car wash concerns were prohibited from using any potable water in their operations and had to revert to non-potable water or waterless detergents. No new landscape projects or sports fields were permitted unless irrigated by non-potable water. Borehole water for outdoor residential usage was discouraged in order to preserve groundwater levels. Even the tourist industry was affected by the austere new water measures. Low flow shower heads and greywater systems were installed in guesthouses and hotels and international tourists were sensitised about the city's dire water situation. The hospitality industry experienced a slight drop in tourist numbers during the high summer season. The sale of potable water to ships in the port of Cape Town was rescinded and shipping agents were advised to fill their vessels elsewhere or to use their own desalination machines (Kloppers 2018).

At the end of January 2018, the city council's Disaster Risk Management Centre became operational (Meyer 2018).
Private water entrepreneurs selling non-potable borehole water to an apparently insatiable number of clients also began to emerge (Schoeman \& Marais 2018). Rumours about a complete dry up of water after the ushering in of 'Day Zero' led to public panic sales of $5 \mathrm{~L}$ potable water cans in shopping centres (Brand-Jonker 2018). Level 6B water restrictions were introduced on 1 February. In order to avoid 'Day Zero', Capetonians were requested to limit their consumption to 50 L per person per day and the city council set its target at an aggregated daily consumption of 450 instead of the current 600 million litres. Restaurants began to charge for a glass of water previously served complimentary with meals. The cricket season for clubs and schools in the Cape Town metropolitan area was shortened by 2 months because the level 6B water restrictions prohibited even the use of borehole water to irrigate sports fields. At the same time, the water crisis was beginning to affect the lucrative Cape real estate market negatively. A $5.5 \%$ drop in property values was reported (Barnard 2018; Nel 2018). Nevertheless, the domestic quest for more water continued unabated. Between January and December 2017, the number of newly drilled private boreholes in the Cape metropolitan area registered by the city council rose from 1500 to 23000 (De Kock 2018).

Amidst the water crisis, Mayor Patricia de Lille, who increasingly began to manage the threatening disaster in her personal capacity, aroused the ire of Cape Town's ratepayers. Because of a drastic drop in water consumption as a result of the accumulated water-saving measures, the city's revenues dropped accordingly. The CCT's estimated water budget deficit ballooned to R1.7 billion for the 2017-2018 financial year, based on consumption figures for October 2017. The mayor proposed that an additional 'drought charge' be levied on certain properties. The proposed levy would be based on property values and calculated at between $10 \%$ and $11 \%$ of the rates portion of the municipal account to pay for the shortfall and the costs incurred by the council for providing alternative sources of water. However, citizens perceived the proposed levy to be nothing but an ironic 'punitive tax' for adhering to the council's water preservation campaign. Many Capetonians incurred huge costs by installing water-efficient devices, grey water solutions and rainwater harvesting tanks - all at their own expense while no tax savings or rebates were offered by the city council. Enraged taxpayers even hinted that the implementation of such measure could cost the ruling party in the city council, the Democratic Alliance (DA), dearly in the next municipal elections due in 2019 (Steenkamp 2018).

Although De Lille explained that the drought charge would provide an income of R1bn per annum over the next 3 years to finance emergency water projects, water delivery and sanitation services, public outcry against these proposals mounted. Influential civic organisations such as the Greater Cape Town Civic Association and the Organisation Undoing Tax Abuse accused the city council of ignoring a process of public participation to debate the validity of a drought charge. According to these organisations, an 'utterly faulty' 
method, based on property values only instead of water consumption, was used to appraise properties on which the drought charge would be made applicable. The Cape Town Chamber of Commerce argued that 4 years prior to the proposed drought charge, the council had already increased water tariffs to twice that of consumer's inflation. Even the DA-controlled Western Cape provincial government officially objected to the city council's proposed drought charge (Brits 2018; Steenkamp 2018). A new civic initiative specifically to protest the mayor's proposed drought charge, Stop CCT, saw the light (Breytenbach 2017b).

By January 2018, the city council had already received more than 45000 comments on the proposed drought levy and it became clear that the overtly negative response of Cape Town residents to the proposals did not augur well for the popularity of the DA-controlled city council. At the end of January, DA leader Mmusi Maimane took political control of the city's drought management because he was 'not fully satisfied with how the city has responded to the water crisis' and because communication on the issue 'has in some instances fallen short'. The mayor, Patricia de Lille, was stripped of responsibility for responding to the water crisis, and control was transferred to a new drought management team consisting of Deputy Mayor, Ian Neilson, and mayoral committee member for water and waste services, Xanthea Limberg. According to Neilson, the DA mayoral committee was not part of the decision-making process regarding the drought, the latter which rested 'solely in the hands of the mayor' (Pieterse 2018).

Finally, as late as 13 March 2018, the national government classified the drought in the Western Cape a national disaster, which gave the provincial government access to emergency funds of R165 million for drought relief projects (Essop 2018; Meyer 2018; Nienaber 2018). A welcome reprieve for the CCT's water dilemma also came from the Groenland Water Users Association (GWUA) in the Elgin-Grabouw valley. At the end of their harvest season, deciduous fruit farmers from this area donated surplus water to the city from the GWUA's private dams. For a period of 60 days, about 10 billion litres were released from GWUA dams and relayed to the city's Upper Steenbras dam. Because of this replenishment of the city's dwindling water supply, as well as good compliance by Capetonians to decrease their water consumption according to water restriction regulations, 'Day Zero' could be postponed indefinitely beyond July 2018. Only if no rains fell during the winter of 2018 would a 'Day Zero' be set for 27 August. By March 2018, DA leader Maimane declared that the CCT's water use had dropped to between 510 million and 520 million litres per day, or about $60 \%$, in comparison to the 1.2 billion litres consumed daily in February 2015 (Theron \& Brits 2018). Simultaneously, the metro made available an additional 10 million litres of treated waste water for industrial use and toilet flushing (Anonymous 2018).

Nevertheless, the drought wrought havoc on Western Cape agriculture because of many farmers' water quotas from the city's dams being cut by $60 \%$ by the DWS. In the financial year of 2017-2018, production in the agricultural sector fell by $20.4 \%$ putting 30230 farm labourers out of work. Economic losses were estimated to be in the vicinity of R5.9bn and the agricultural damages about R14bn as a result of the drought (Boonzaaier 2018; Theron \& Brits 2018).

\section{The political fallout of the drought - Who is to blame?}

Given the characteristics and structure of South African politics, and Western Cape politics in particular, it came as no surprise that the CCT's water shortages eventually degenerated into a huge political fallout and fierce finger pointing across various levels of government about who is to blame for the crisis. In 2014, De Lille's Independent Democrats (ID) merged into the DA and per agreement she became Cape Town's new executive mayor after the municipal elections of 2011. Since the 2016 municipal elections, the DA controlled the city council with a majority of $66.7 \%$. The ANC forms the largest opposition party in the council with $24.7 \%$. Like the CCT, the Western Cape is controlled politically by the DA. This means that the relationship between the national government and the Western Cape is complicated, as the water crisis has shown (Bourblanc 2018; Olivier 2017a).

A fractured political control of water management structures during desperate times such as the CCT drought obviously holds a potential problem of how to solve the crisis and criticism could be launched at all three tiers of government in dealing with the issue. The nature of South African water legislation contributes to this lack of collaboration dilemma. The South African Constitution created separate responsibilities for water resource management and water services. The raw water infrastructure (surface and ground water) is the national government's responsibility, while water services (water treatment, distribution, etc.) are local governments' responsibility. There are different legal mandates and primary roles related to water infrastructure. The DWS is governed by the National Water Act and the Water Services Act. Municipalities are governed by the Water Services Act and municipal legislation. In essence, the three spheres of government sent out different messages about the seriousness of the drought (Parliamentary Monitoring Group 2017a). It also transpired that political expedience and opportunism were significant obstructive factors to efficient intergovernmental coordination and intervention in dealing with the disaster.

A major problem in dealing with the CCT drought lies within the DWS controlled by the ANC government. The DWS seemed to have become dysfunctional and to have fallen into disarray. As early as 2015, an organisation for the agricultural sector, Agri Western Cape, warned the national government about a looming disaster in the province should it not intervene timely. However, by 2016, the then Minister for Agriculture, Forestry and Fisheries, Senzeni Zokwana, was still of the opinion that it would be 'premature' to 
declare the drought a national disaster. When the drought began to take its toll on provincial dam levels in the Western Cape, the DWS took no action to curtail agricultural water use in 2015/2016 but actually allocated too much water to agriculture in the province. This pushed the demand for water beyond the capacity of the supply system and consumed Cape Town's safety buffer of 28000 megalitres. In response to low winter rainfalls in 2015, the Western Cape provincial government took preventative action and applied to the national government for R35m to increase water supplies by drilling boreholes and recycling water, but the request was rejected, possibly because dams were still $75 \%$ full.

The following year, the national government agreed to recognise only five of the 30 Western Cape municipalities as drought disaster areas but significantly Cape Town was not included. However, by October 2017, the national government had still not released the promised funds. Cape Town mayor Patricia de Lille appealed directly to the DWS for disaster relief funding, but the request was rejected by the DWS regional director who believed that the situation was 'not yet at crisis level'. In the light of the DWS's refusal to declare the drought, a national disaster Western Cape DA Premier Helen Zille accused the ANC national government of 'leaving the Western Cape in the lurch'. The national government still seemed to be focused largely on remedial action rather than on preventive mechanisms (Anonymous 2017b; Brits 2018; Olivier 2017a).

But eventually, it came to light that the DWS was in financial dire straits as the Western Cape was with water. A civil society group, the South African Water Caucus, revealed that the national government's reluctance to release drought relief funding stemmed from spiralling debt, mismanagement, maladministration and corruption in the DWS. In 2017, the department was R1.463bn in arrears with contractors and by the end of that year, it had exceeded its budget by R110.8m. By 2018, the DWS had a R2.675bn overdraft with the South African Reserve Bank, which had been frozen by the Treasury Department. As a result, the then DWS Minister, Nomvula Mokonyane, was unsuccessful in drawing private investors into the department's water provision schemes and no financiers were willing to lend them any money. Furthermore, there was no stability, and a lack of capacity in the department, poor decision-making, wasteful and irregular overexpenditure and lack of transparency were concerns and planning was based on old data. Three Deputy DirectorGenerals were suspended and there were 900 vacancies in the DWS (Bourblanc 2018; Brits 2018; Olivier 2017a; Parliamentary Monitoring Group 2017a, 2017b).

According to Turton (2015), many experienced and highly qualified DWS specialists (e.g. hydraulic engineers) were being placed under great pressure to leave, long before they reached retirement age, because of transformation imperatives. Many have succumbed to the pressure and resigned. These individuals were replaced by people with fewer skills and who rarely had the same qualifications and experience, thereby creating a vacuum in professional expertise. This also rendered the department heavily dependent on consultants for the delivery of critical services, including data collection and analysis. Commercial consultants quickly learnt that data equated to money, and began recycling much of the same data every time a new consulting report needed to be produced. This resulted in multiple billings for the same data, but this had to be accepted as a necessary evil as the state's own capacity had declined. The level of politicisation in the DWS became so high that decision-making was no longer rooted in hydrological realities. This situation had the effect of infrastructure not being maintained or repaired. Maintenance negligence by the department caused silt to fill one of the feeding channels to the Voëlvlei dam, one of Cape Town's major reservoirs, and 7.5 million $\mathrm{m}^{3}$ water was lost in 2016. Because of the DWS's budget restraints, the Western Cape provincial government used R3.5m of its own funds to complete essential repairs to the Voëlvlei feeding channels (Barnard 2017).

The eventual indefinite postponement of 'Day Zero' also reverberated in the political fallout over the Cape Town drought crisis. On the one hand, opposition parties accused the DA-controlled city council of ignoring constant timely warnings about changing rainfall patterns, climate change and an increasing population (Diko 2018). On the other hand, the council's constant postponement of 'Day Zero' could easily have rendered some plausible credence to the ANC opposition's accusations of deliberate scaremongering tactics, 'creating' a water crisis and of sowing confusion among Capetonians by the DA in order to benefit its preferred private water contractors. Although Director of Water and Sanitation: CCT, Peter Flower, denied such tactics by the council and claimed that the term had been created in the social media, he conceded that increased tariffs, the lowering of water pressure, plus the potential of a 'Day Zero', were attempts to make citizens and businesses of the CCT reduce water usage. Because of the public response and declined usage, such a day could be moved beyond July 2018, he claimed (Prince 2018).

Daily Maverick columnist Rebecca Davis (2018) argued that the 'Day Zero' concept was largely a communications tool designed to focus Capetonians' minds on the severity of the water crisis. She divides the city's communications on the crisis into three periods: ineffectual, punitive and congratulatory. During the 'ineffectual' phase, the slogan

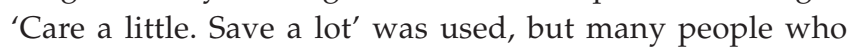
had easy access to water took it and its availability for granted. Consequently, the CCT contracted former DA leader Tony Leon's communications agency, Resolve Communications, which offered specific skills and vast experience in government crisis communication strategies and behaviour change. Resolve Communications thus ushered in the 'punitive' phase and suggested the term 'Day Zero' as a means to induce Capetonians to change their attitudes towards the water crisis. With Mayor De 
Lille's 'point of no return' statement, announcing that 'Day Zero' was virtually certain, things took a decidedly dramatic turn as it changed the momentum to communicate the message about the drought situation. This approach led to the intervention of the DA party leadership. Significantly, Resolve Communication's contract with the CCT did not extend beyond the revocation of De Lille's water management powers.

Even Western Cape Premier Helen Zille (2018) conceded that the 'Day Zero' messaging helped the city council to achieve its water-saving targets, but also acknowledged that as a concept, it was becoming a destructive strategy with some seriously negative consequences, especially for the economy. She highlighted the fact that water consumption dropped significantly, from over 600 million litres per day to around 520 million litres. This was driven by a combination of tight new restrictions, significant tariff increases, a deliberate drop in water pressure, and residents' compliance with watersaving measures. In addition, at the end of their irrigation season, three agricultural irrigation boards around Grabouw and Elgin agreed to having their surplus water cut entirely. The GWUA donated 10 billion litres of water to the city and augmentation began to come on stream by the targeted dates. Talk of 'Day Zero' appeared to have been receding in the city's communications strategy. Therefore, Davis (2018) claims that the DA then was stepping into a situation which was guaranteed to look much more positive and rosier and from February 2018 onwards, communications from both the CCT and the DA started to reflect a 'congratulatory' phase. A tone of pride began to creep into communications suggesting that Cape Town would not only prevail, but also set an example to the rest of the world.

But apart from finger pointing by the opposition, the political fallout resulting from the water crisis had much to do with factionalism, turf wars and possible witch hunts within the DA-controlled city council as well. Central in this fracas is the position and personality of CCT Executive Mayor Patricia de Lille. Her leadership style has been described as 'autocratic and divisive', 'legendary opportunistic and brusque' as well as 'utterly problematic for the successful functioning of her administration and caucus'. She also 'acted unreasonably in ways that bedevilled internal party cooperation and rejected decisions of the party structures' (Rooi 2018).

It transpired that De Lille was steadily creating a bureaucracy controlled by faithful former ID followers which created resentment among the DA caucus in the city council. Besides being blamed for confusing communication with the public, she was also accused of 'chaotic' crisis management, poor decision-making, 'unrealistic' and 'hopelessly inadequate' drought plans and time frames implementation in dealing with the drought situation. The DA executive thus lost its confidence in the mayor's ability to deal with the drought crisis. The executive also instructed its city councillors to vote against De Lille's proposed drought levy. Newspapers speculated that the DA's support in the Western Cape had decreased sharply and that the water crisis affected DA support even more than the crisis surrounding the mayor (Steenkamp 2018). In addition to these accusations, the DA laid criminal charges against De Lille for bribery and corruption with regard to compensation, personal home improvements and financial mismanagement. She also had to face a disciplinary hearing in terms of 'corrupt' staff appointments, nepotism and interference in the allocation of contracts, all which allegedly led to the withdrawal of the city council's clean audit status by the Auditor-General (Meyer \& Barnard 2018). Clearly, the DA and De Lille had fallen out and the CCT drought issue played a major role. ${ }^{2}$

De Lille's disciplinary hearing and corruption charges had another negative impact on the city's water crisis. For 3 months, from October to December 2017, the DA's efforts to depose the mayor of Cape Town also brought the programme for water augmentation projects to a standstill. No decisions were made and the technical managers responsible for the installation of desalination plants could not get permission to go ahead, causing these water augmentation projects to run behind schedule (Burger 2017; Gosling 2018).

Besides the political factors, the Cape Town city council also stands to be blamed for lack of proper planning decisions by its water officials in terms of its share in the drought crisis. According to Mike Muller (2017a), former Director-General of the then Department of Water Affairs (DWA), increased water consumption had been tracked systematically and reported by the Strategy Steering Committee responsible for overseeing the implementation of the Department's Western Cape Water Supply System Reconciliation Strategy. The study did not make a single projection of future demand, but provided a range of high and low estimates. If the CCT had been successful in implementing its 8-year Western Cape water demand management strategy, the next reconciliation intervention could have been delayed until 2015. Back in 2007, the choice, among various other options, appeared to be between using the Table Mountain Group of aquifers or an augmentation of the supply into the Voëlvlei dam from the Berg River.

At the end of the above-average 2013 rainy season, the outlook still seemed to be encouraging. On the basis of the apparent progress, it was suggested that the programme of interventions should be revised to 'try to keep the future growth in water requirements below two percent'. The CCT argued that there was enough time to make decisions regarding the next intervention. By 2014, the status report was confident that since 2010, there had been a decline in total domestic use for the Western Cape Water Supply Scheme (WCWSS), 'which was a direct result of the decreasing consumption by the CCT'. The report concluded that because of the good 2014 winter rains and the fact that most of the dams of the WCWSS were nearly full, 'there was no need for implementing restrictions'. Not only did the CCT estimate 2.At the time of writing this article, the criminal charges and the disciplinary hearing against De Lille had not yet taken effect. 
that there was no need for restrictions, but neither was there any immediate need to start with augmentations. It had been agreed that the Voëlvlei augmentation would be the first to be implemented, but this was stalled pending the conduct of an environmental impact assessment by the DWA. The warning system thus failed to raise the alarm because the people concerned did not have a clear mandate to spell out the consequences of stalling the Voëlvlei augmentation scheme (Muller 2017b).

Although there was no sense of urgency yet, the problems had already begun. An April 2015 strategy meeting reported that 'the dam levels are lower than normal at this time of the year, but the rain season will hopefully bring relief for the current dry situation'. As that did not occur, it rapidly became clear that the predictions of 2014 were hopelessly optimistic. Muller (2017a) argues that the fatal mistake the CCT made was to believe that its water demand management campaign had been successful. The CCT was of the opinion that the slowdown and subsequent reduction in growth of water requirement in the years 2011-2014 was mainly because of the effect of implementing water demand management measures. The city believed that it could be expected that those reductions would be maintained. The report suggested that no new water would be required until 2019 at the earliest, and more likely 2024. Although it was becoming clear that the desalination and water reuse options would be too expensive, no immediate decision was taken to proceed with Voëlvlei, which was now the obvious first option. The situation was aggravated by the then DWA's failure to impose restrictions on agricultural water use in 2015/2016, because the summer irrigation season had already started.

Muller (2017a) thus concurs with observations by Olivier (2017a) and Brits (2018) that apparently there was some overallocation of water to agriculture. But for Muller, the key was the increase in Cape Town's consumption, hardly unexpected given the continued increase in the urban population and three seasons of hot, dry weather.

\section{Conclusion}

By the time of writing this article, the Cape Town water crisis was not over yet. Nevertheless, the following question can be asked: what have Capetonians learnt thus far from their drought experience? In a number of ways, the CCT's response to dealing with its water crisis resembles more or less the experiences of Melbourne, Barcelona and São Paolo: population expansion; a lack of foresight by the authorities to heed warnings about looming water scarcities in favour of real estate developments, industrial and agricultural considerations; political battles and controversy; differences in strategy of dealing with the crisis (Melbourne being the exception) as well as negative publicity. There are also similarities with regard to practical solutions to decrease water usage. Without implementing similar water-saving strategies such as these, the CCT's reservoirs probably would have been empty before the 2018 winter rainy season (Olivier 2017c; Slaughter \& Mantel 2018).
Also, in Australia, the Queensland Water Commission began showing residents how dam levels were dropping. It was able to convince customers that intensified water restrictions were absolutely necessary (Olivier 2017b). Although urban water efficiency was the quiet achiever in Australia, White, Turner and Chong (2016), Bourblanc (2018), Muller (2017a) and Olivier (2017c) argue that human behaviour is difficult to predict and that it would be perilous to assume as a basis for future planning that $100 \%$ continuance of 'good behaviour' among Capetonians will be achieved. While the water-saving the city has achieved can be applauded, the risk is that residential use will bounce back to old habits as soon as the obvious threat passes. Therefore, Cape Town's water culture must be changed to avoid stressful water crises because water restrictions are not popular decisions and politicians are often reluctant to impose them.

There are, of course, differences as well between these cities and Cape Town's handling of its own drought. Cape Town could learn from the example of the Victorian state government's funding of water rebate and exchange programmes with regard to water reduction devices, grey water systems and rainwater harvesting for business and residential water users (Low et al. 2015; Steenkamp 2018). Such rebates could only encourage more Capetonians, especially among poorer socio-economic households, to consider the implementation of water-saving devices (Slaughter \& Mantel 2018). On the other hand, the crisis has positioned Cape Town at the forefront of water resilience and its water-reducing strategies seem to be even more effective than those of Melbourne and other cities. Cape Town succeeded in reducing its water usage by about $57 \%$ within 3 years but it took Melbourne about 12 years to reach more or less the same levels. Between 2012 and 2017, California could only manage to reduce its water usage by $27 \%$ and São Paolo by 21\% (Breytenbach 2018). The CCT should avoid constructing costly large-scale, permanent desalination plants until all other water augmentation options such as recycling, storm water harvesting and underground sources are exhausted. Melbourne and Barcelona have shown that large-scale desalinations plants are extremely expensive to maintain on a permanent basis and could, once a severe water crisis has passed, become white elephants (Low et al. 2015; Nash 2008; Olivier 2017d; Rodina 2017; Tam 2016; Van Zyl 2018).

Punitive tariffs, as measures to discourage excessive domestic and commercial water overuse, proved to be quite effective in São Paolo and Cape Town. However, negative publicity regarding a water crisis, as transpired in Barcelona and Cape Town, tends to create political backlash. In Cape Town, Executive Mayor De Lille's proposed additional 'drought charge' to augment a water budget deficit was perceived by citizens as a 'punitive tax' for adhering to the council's water preservation campaign and as a discriminatory measure to target a specific socio-economic group of rate-paying households. It had a huge negative backlash for the popularity 
of the DA-controlled city government and led to the rise of influential civic organisations which successfully opposed the implementation of the drought levy.

These initiatives by the mayor, too many confusing messages on the city's progress to deal with the drought and the negative and scaremongering effect on Capetonians of the possible introduction of a so-called 'Day Zero' scenario, even if ironically it might have contributed to public adherence to austere water-saving measures, eventually led to a political fallout between De Lille and her own party. Not only has she been stripped of responsibility for responding to the water crisis by her own party but she still has to face a disciplinary hearing by the DA which could lead to her expulsion from the party. De Lille enjoys a substantial personal political following among certain sections of the Cape Town electorate and an expulsion could have major negative repercussions for the DA-controlled city council in the next municipal elections (Harris, Zhao \& Visser 2018; Steenkamp 2018; Winter 2017). On the other hand, the Melbourne example has shown that clear, credible communication and government and utility programmes that rally community support and maximise public participation for lowering household water demand are of vital importance during a drought crisis (White et al. 2016).

Finally, according to Bourblanc (2018), the main problem in dealing effectively with Cape Town's drought crisis is the politically fractured multi-tiered management which is also affecting the entire country's water system. The Cape Town situation has laid bare the inadequacies in the country's water management regimes and the city's misfortune could be a wake-up call for the whole country's water infrastructure inadequacies. In comparison, Australia responded with an integrated government approach to the Millennium Drought which forced cooperation between the various tiers of government and water management agencies (Low et al. 2015; Slaughter \& Mantel 2018). The key to future water security for Cape Town, or any other South African city for that matter, is competent and adequate long-term planning. Cape Town's water supply system should be made even more resilient by expanding to water resources that are less drought-prone. A serious lesson of the present Cape Town drought is that it should never again be presumed that the city's expenditure on water supply schemes could be put on hold simply by saving the existing supply in the belief that it will remain stable.

\section{Acknowledgements}

Funding for this article was made possible by a research grant from the National Research Foundation.

\section{Competing interests}

The author declares that he has no financial or personal relationships which may have inappropriately influenced him in writing this article.

\section{References}

Anonymous, 2017a, "'Stubborn" Capetonians still using too much water', WAMTech Bulletin 28(4), 1.

Anonymous, 2017b, 'South Africa's drought preparedness - Too little too late?', The Water Wheel January/February, pp. 24-25.

Anonymous, 2018, 'It's time to come clean', Cape Times, 22 January, p. 8.

Barnard, M., 2017, 'Vingers nou gewys oor kanale in W-Kaap', Die Burger, 04 August, p. 10.

Barnard, M., 2018, 'Watertariewe drasties verhoog', Die Burger, 20 January, p. 4.

Barnes, J., 2016, 'It's essential to manage water', Cape Times, 22 March, p. 9.

Boonzaaier, D., 2018, 'Wes-Kaap: Verliese weens droogte styg', Rapport Sake, 04 March, p. 3.

Botha, S., Private Photo Collection, Villiersdorp, January 2018.

Bourblanc, M., 2018, 'Cape Town should serve as a wake up call for managing water in South Africa', The Conversation, viewed 26 February 2018, from https:// theconversation.com/cape-town-should-serve-as-a-wake-up-call-for-managingwater-in-s....

Brand-Jonker, N., 2018, 'Bottelwater: Shoprite verkoop 200\% meer', Die Burger, 08 February, p. 16.

Breytenbach, J., 2017a, 'Nóg strenger waterperke van krag in Kaap', Die Burger, 04 September, p. 1

Breytenbach, J., 2017b, 'Waterheffing: Kapenaars maak stem dik', Die Burger, 22 December, p. 8.

Breytenbach, J., 2018, 'Kaapstad oortref waterbesparingsrekords', Die Burger, 07 March, p. 5.

Brits, E., 2017, 'Kaapstad soek nou water in klip', Die Burger, 20 November, p. 5.

Brits, E., 2018, 'Waarskuwings oor droogte gaan so ver terug as 2007', Die Burger, 23 January, p. 4.

Burger, A., 2017, 'Beloftes, maar geen boorgate!' Rapport, 22 October, p. 5.

City of Cape Town, 2011, The water cycle, CCT Press, Cape Town, pp. 12-20.

Davies, B. \& Day, J., 1998, Vanishing waters, University of Cape Town Press, Cape Town, pp. 313-315, 339-340.

Davis, R., 2018, '\#CapeWaterGate: In the end, what was Day Zero all about?', Daily Maverick, 14 March, viewed 26 March 2018, from https://www.dailymaverick. co.za/article/2018-03-14-capewatergate-in-the-end-what...

De Kock, A., 2018, 'Kapenaars sink boorgate dat dit klap', Die Burger, 09 December, p. 11.

Diko, Y., 2018, 'Cape Town's water crisis: Is this the deadliest failure of the DA government?', Daily Maverick 15 February, viewed 15 February 2018, from https://www.dailymaverick.co.za/opinionista/2017-05-21-cape-towns-watercrisis-is-t....

Essop, P., 2018, 'Metro maak nie sy inwoners bang, sê hoë', Die Burger, 08 February, p. 10.

Felix, J., 2017, 'Spoel toilette nie meer as tien maal per dag', Die Burger, 01 June, p. 8

Gerberg, J., 2015, 'A megacity without water: São Paolo's drought', Time, viewed 02 February 2018, from http://time.com/4054262/drought-brazil-video/

Goodman, A., 2008, Spain suffers worst drought, CNN Madrid Bureau, Madrid, viewed 22 January 2018, from http://edition.cnn.com/2008/WORLD/europe/04/18/ spain.drought/

Gosling, M., 2018, 'Boorde en windergde krimp', Die Burger, 23 Maart, p. 4.

Harris, L., Zhao, J. \& Visser, M., 2018, 'Nudging the city and residents of Cape Town to save water', The Conversation, viewed 05 March 2018, from https:// theconversation.com/nudging-the-city-and-residents-of-cape-town-to-savewater-92192?...

Heymans, C., 2018, 'Cities and water: Some lessons from very water-scarce places', LitNet, 05 March, viewed 09 March 2018, from http://www.litnet.co.za/citieswater-lessons-water-scarce-places/

Ismail, A., 2018, 'State ignored water alarm bells for 47 years', Cape Argus, 25 January, p. 12.

Janse van Rensburg, A., 2015, 'Damme bly kommerwekkend leeg ondanks goeie reënval', Die Burger, 16 June, p. 4

Kloppers, E., 2018, 'Waterkrisis knou Kaapse hotelbedryf', Rapport, 28 January, p. 1.

Low, K.G., Grant, S.B., Hamilton, A.J., Gen, K., Saphores, J.-D., Arora, M., Feldman, D.L., 2015, 'Fighting drought with innovation: Melbourne's response to the Millennium Drought in Southeast Australia', WIREs Water 2015, 1-14. https://doi.org/ 10.1002/wat2.1087

May, A., 2018, 'City's sights on Day Zero', Cape Argus, 29 January, p. 1.

Meyer, W., 2018, 'Rampbestuursentrum van vandag operasioneel', Die Burger, 29 January, p. 4.

Meyer, W. \& Barnard, M., 2018, 'De Lille weier aanbod', Die Burger, 30 January, p. 2.

Muller, M., 2017a, 'Understanding the origins of Cape Town's water crisis', Civil Engineering, June, 11-16.

Muller, M., 2017b, 'Lack of urgency over water crisis a critical concern as the taps run dry', Business Day, 19 April, viewed 08 March 2018, from https://www. businesslive.co.za/bd/opinion/2017-04-19-lack-of-urgency-over-water-crisis-a- 
Nash, E., 2008, Spain's drought: A glimpse of our future?, The Independent, London, viewed 22 January 2018, from http://independent.co.uk/news/world/europe/ viewed 22 January 2018 , from http:///
spains-drought-a-glimpse-of-our-future/

Nel, C.-A., 2018, 'Wes-Kaap se krieketseisoen word deur droogte uitgeboul', Die Burger, 02 February, p. 4

Nienaber, M., 2017a, 'Water raak nou min in Kaapstad', Die Burger, 25 April, p. 3.

Nienaber, M., 2017b, 'Reënwolke bly dié week weg', Die Burger, 04 July, p. 6.

Nienaber, M., 2018, 'Droogte tot nasionale ramp verklaar', Die Burger, 14 February, p. 9.

Nikolau, L., 2015, 'Water crisis in Brazil: Why the largest city in the Americas is drying out', Humanosphere, viewed 02 February 2018, from http://www.humanosphere. org/environment/2015/12/water-crisis-brazil-largest-city-a....

Olivier, D., 2017a, 'Cape Town's water crisis: Driven by politics more than drought' The Conversation, viewed 14 December 2017, from https://theconversation.com/ cape-towns-water-crisis-driven-by-politics--more-than-drought

Olivier, D., 2017b, 'How Cape Town can win support for the next round of water cuts', The Conversation, viewed 20 October 2017, from https://theconversation.com/ how-cape-town-can-win-support-for-the-next-round-of-water-cuts-8....

Olivier, D., 2017c, 'Water shortages in Cape Town are here to stay. What the city can learn from others', The Conversation, viewed 18 July 2017, from https:// theconversation.com/water-shortages-in-cape-town-are-here-to-stay-what-thecity-can-lea...

Olivier, D., 2017d, 'Cape Town water crisis: 7 myths that must be bust', The Conversation, viewed 23 November 2017, from https://theconversation.com/ cape-town-water-crisis-7-myths-that-must-be-bust-86582?utm_medi....

Patterson, B., 2015, 'What Australia can teach the world about surviving drought', E\&E News, viewed 05 February 2018, from https://www.scientificamerican.com/ article/what-australia-can-teach-the-world-about-....

Parliamentary Monitoring Group, 2017a, 'MTBPS implications on water sector: Department', Water Economist, Black Business Council responses, 07 November, pp. 2-3, viewed 23 November 2017, from https://pmg.org.za/committeemeeting/25432/?utm_campaign=minute-alert\&utm_sou....

Parliamentary Monitoring Group, 2017b, Department of Water and Sanitation on Quarter 1 performance, with Minister and Deputy Minister, 13 September, pp. 1-7, viewed 27 September 2017, from https://pmg org za/committeemeeting/25003/?utm campaign=minute-alert\&utm_sou....

Pieterse, M., 2018, 'Cape Town water crisis: Crossing state and party lines isn't the answer', The Conversation, viewed 06 February 2018, from https:// theconversation.com/cape-town-water-crisis-crossing-state-and-party-lines-isntthe-answer-90861

Prince, L., 2018, 'Minister wil nie byt aan Dag Zero', Die Burger, 29 January, p. 1.

Rigby, C., 2015, 'Drought drives water shortage to critical stage in Sao Paolo, Brazil', LA Times, Los Angeles, viewed 02 February 2018, from http://latimes.com/world/ brazil/la-fg-brazil-drought-20150820-story.html

Rodina, L., 2017, 'Cape Town needs new approach to manage water', The Conversation viewed 18 July 2017, from https://theconversation.com/cape-town-needs-a-newapproach-to-manage-water-79441?utm_me...
Rooi, J., 2018, 'Eerste skoot in DA-oorlog tref: De Lille-mag beperk', Rapport, 21 January, p. 8.

SADC, 2016, 'SADC regional situation update on El Niño-induced drought', SADC News Bulletin, 15 May, p. 1.

Schoeman, L. \& Marais, J., 2018, 'Wynkarweier nou straks waterboer', Die Burger, 30 January, p. 4.

Slaughter, A. \& Mantel, S., 2018, 'What southern Africa can learn from other countries about adapting to drought', The Conversation, viewed 12 February 2018, from https://theconversation.com/what-southern-africa-can-learn-from-othercountries-about-adapting....

Stauffer, C., 2016, 'Drought ends Brazil's Sao Paolo but future still uncertain', Reuters, viewed 02 February 2018, from https://www.reuters.com/article/us-brazil-water/ drought-ends-in-brazils-sao-paolo-but....

Steenkamp, L.-A., 2018, 'Why the drought levy tabled by Cape Town's mayor is unfair', The Conversation, viewed 17 January 2018, from https://theconversation.com/ why-the-drought-levy-tabled-by-cape-towns-mayor-is-unfair-90119....

Streek, B., 1990, 'City will run out of water "in 17 years"', Cape Times, 26 April, p. 4.

Tam, L., 2016, 'Learning from Australia's “Millennium Drought"', The Urbanist 551 , 1-4, viewed 05 February 2018, from http://www.spur.org/publictions/urbanistarticle/2016-07-07/learning-australia-s-mill...

Theron, N. \& Brits, E., 2018, 'Ons kán Dag Zero vryspring as...', Die Burger, 2 Maart, p. 1.

Turton, A., 2015, 'The looming water crisis, and its causes', Politicsweb, viewed 31 October 2017, from http://www.politicsweb.co.za/news-and-analysis/water-thenext-eskom--ir

Van Zyl, W., 2018, 'Desalination: Global examples show how Cape Town could up its game', The Conversation, viewed 02 February 2018, from https://theconversation. com/desalination-global-examples-show-how-cape-town-could-up-its-ga....

Visser, W.P., Private Water Research Photo Collection, May 2018.

White, S., Turner, A. \& Chong, J., 2016, 'What California can learn from Australia's 15 -year millennium drought', The Conversation, viewed 05 February 2018, from https://theconversation.com/what-california-can-learn-from-australias-15-yearmillennium-drou...

Winter, K., 2017, 'What's driving Cape Town's water insecurity, and what can be done about it', The Conversation, viewed 10 August 2017, from https://theconversation. com/whats-driving-cape-towns-water-insecurity-and-what-can-be-done-a....

Winter, K., 2018, 'Day Zero is meant to cut Cape Town's water use: What is it and is it working?', The Conversation, viewed 26 February 2018, from https:// theconversation.com/day-zero-is-meant-to-cut-cape-towns-water-use-what-isit-....

World Weather \& Climate Information, 2018, viewed 31 January 2018, from https:// weather-and-climate.com/average-monthly-precipitation-Rainfall-inches,Cape Town

Zille, H., 2018, 'From the Inside: Four changes that rewrote the Day Zero narrative', Daily Maverick, 12 March, viewed 26 March 2018, from https://www. dailymaverick.co.za/opinionista/2018-03-12-from-the-inside-four-change.... 